\title{
Uric Acid and Cardiovascular Risk
}

\author{
Daniel I. Feig, M.D., Ph.D. ${ }^{1}$, Duk-Hee Kang, M.D. ${ }^{2}$, and Richard J. Johnson, M.D. ${ }^{3}$ \\ 1 Baylor College of Medicine, Houston
}

2 Ewha Womans University School of Medicine, Seoul, Korea

3 University of Colorado Health Sciences Center, Denver

\begin{abstract}
An association of gout with hypertension, diabetes, kidney disease, and cardiovascular disease has been observed since the late 19th century. Early investigators, such as Frederick Mahomed, Alexander Haig, and Nathan Smith Davis, hypothesized that uric acid might be a cause of hypertension or renal disease. In 1897, in his presidential address to the American Medical Association, Dr. Davis wrote, "High arterial tension in gout is due in part to uric acid or other toxic substances in the blood which increase the tonus of the [renal] arterioles." 1 Since agents that lower uric acid levels were not available earlier in Davis's career, however, there were no studies indicating that uric acid had a causal role in these conditions.
\end{abstract}

The association between uric acid and cardiovascular disease was largely ignored until the mid-1950s and early 1960s, when it was rediscovered. ${ }^{2,3}$ Since then, a number of epidemiologic studies have reported a relation between serum uric acid levels and a wide variety of cardiovascular conditions, including hypertension, 2 metabolic syndrome,${ }^{4}$ coronary artery disease, ${ }^{5}$ cerebrovascular disease, ${ }^{6}$ vascular dementia, ${ }^{7}$ preeclampsia, ${ }^{8}$ and kidney disease. ${ }^{9,10}$ The relation between uric acid and cardiovascular disease is observed not only with frank hyperuricemia (defined as more than $6 \mathrm{mg}$ per deciliter [ $360 \mu$ mol per liter] in women and more than $7 \mathrm{mg}$ per deciliter [ $420 \mu \mathrm{mol}$ per liter] in men) but also with uric acid levels considered to be in the normal to high range ( $>5.2$ to $5.5 \mathrm{mg}$ per deciliter [310 to $330 \mu \mathrm{mol}$ per liter]). ${ }^{11-13}$

The relative importance of these associations remains controversial. Some experts, such as the Framingham Heart Study group, have argued that uric acid is not a risk factor for cardiovascular disease and that clinicians should rely only on classic risk factors in patient assessment. ${ }^{14}$ Nor have serum uric acid levels been considered a cardiovascular risk factor by major professional societies. 15,16

This review summarizes relevant studies concerning uric acid and possible links to hypertension, renal disease, and cardiovascular disease. Although such evidence is mounting, it does not yet support the general treatment of asymptomatic hyperuricemia to reduce cardiovascular risk. However, there would seem to be sufficient evidence to warrant clinical trials to determine whether lowering uric acid levels would be of clinical benefit in the prevention or treatment of cardiovascular and renal diseases.

Address reprint requests to Dr. Feig at the Department of Pediatrics, Renal Section, Baylor College of Medicine, Houston, TX 77030, or at E-mail: dfeig@bcm.tmc.edu.

Dr. Johnson reports being listed as an inventor on several patent applications related to the role of uric acid in hypertension and the metabolic syndrome and being an author of The Sugar Fix, a book for the lay public on fructose and uric acid published by Rodale in 2008. No other potential conflict of interest relevant to this article was reported. 


\section{URIC ACID AND CARDIORENAL DISEASE — CAUSE OR CONSEQUENCE?}

One difficulty in determining whether uric acid per se should be considered a cardiovascular risk factor is that elevated uric acid levels are often associated with established cardiovascular risk factors (Table 1). For example, uric acid levels are higher in many groups at increased cardiovascular risk, such as postmenopausal women, blacks, and people with hypertension, the metabolic syndrome, or renal disease. The increased risk of cardiovascular disease observed with Westernization of native peoples, immigration to Western countries, and movement from rural to urban communities also correlates with increased uric acid levels. ${ }^{17}$ Furthermore, the sharp rise in hypertension, obesity, diabetes, and kidney disease in the United States over the past 100 years has also been associated with a progressive rise in serum uric acid levels. ${ }^{17}$ Mean uric acid levels in men increased gradually from less than $3.5 \mathrm{mg}$ per deciliter (210 $\mu$ mol per liter) in the 1920 s to 6.0 to $6.5 \mathrm{mg}$ per deciliter (360 to $390 \mu \mathrm{mol}$ per liter) in the 1970s. ${ }^{18-21}$ Women tend to have lower levels (by 0.5 to $1.0 \mathrm{mg}$ per deciliter [30 to $60 \mu \mathrm{mol}$ per liter]) than men, probably because of the uricosuric effect of estrogens. ${ }^{22}$

To investigate the role of uric acid in disease, epidemiologists have often used multivariate analyses to assess whether an elevated uric acid level is an independent cardiovascular risk factor. Using this approach, a number of studies have suggested that uric acid is not independent of other established risk factors, especially hypertension, for the development of cardiovascular disease. ${ }^{14,23-25}$ Consequently, some expert groups have argued that studies indicating uric acid is an independent risk factor did not sufficiently control for other known risk factors. Furthermore, if uric acid were a risk factor, then a mechanism by which uric acid could cause cardiovascular disease should be apparent. Others have posited that one of the main functions of uric acid is its role as an antioxidant, which, if anything, would make it beneficial to people with cardiovascular disease. ${ }^{26,27}$ Finally, the elevation of uric acid levels in patients with cardiovascular disease could simply be a result of the common presence of factors such as reduced glomerular filtration rate, hyperinsulinemia, renal vasoconstriction, or diuretic use (all of which reduce net renal excretion of uric acid) or of alcohol use, tissue ischemia, or oxidative stress (which may increase uric acid generation). ${ }^{28-30}$

A similar argument has been made for the association of elevated uric acid levels with chronic kidney disease. Before drugs that lower uric acid level became available, more than $50 \%$ of patients with gout had some renal insufficiency and nearly $100 \%$ had renal disease at autopsy. 31,32 The kidney lesions in patients with gout are characterized by advanced arteriolosclerosis, glomerulosclerosis, and interstitial fibrosis, often with the presence of urate crystals in the outer medulla. ${ }^{32}$ The presence of such urate deposits gave rise to the name "gouty nephropathy" for this condition. However, the hypothesis that renal injury was caused by the deposition of urate crystals seemed flawed or incomplete, considering that the crystal deposition was focal and thus unlikely to explain the diffuse nature of the disease and that crystals could also be found in normal kidneys in the absence of inflammation. Furthermore, the most characteristic findings, which are advanced arteriolosclerosis and glomerulosclerosis, are indistinguishable from those observed with longstanding hypertension or age-related glomerulosclerosis and may simply reflect the fact that most patients with gout have hypertension and are older. ${ }^{33}$ Consequently, for the past 30 years there has been a widespread belief that uric acid is unlikely to be a risk factor for renal disease. ${ }^{34}$

\section{URIC ACID AND CARDIOVASCULAR DISEASE - A REAPPR AISAL}

Several events have led to the ongoing reappraisal of the role of uric acid in cardiovascular disease. Some studies that have controlled for multiple risk factors suggest that uric acid may be an independent risk factor for both cardiovascular disease ${ }^{13,35-37}$ and kidney disease.

$38-40$ Other studies have noted that an elevated level of uric acid predicts the development of 
hypertension, ${ }^{41-56}$ obesity, ${ }^{48}$ kidney disease, ${ }^{38-40}$ and diabetes. ${ }^{51,57}$ Studies using animal models and cell cultures have identified mechanisms by which uric acid might induce cardiovascular and renal disease, ${ }^{58-60}$ and there have been reports of cardiovascular and renal benefits from lowering uric acid levels in recent preliminary clinical trials. $., 10,61,62$

Should we accept the assumption that to be defined as "causal," a factor must be independent of other risk factors? In effect, this assumption has already been challenged by reports that elevated uric acid levels must be both a direct and an indirect cause of renal disease and cardiovascular disease. For example, Yu and colleagues reported that renal disease developed in $40 \%$ of patients with gout, but they argued that uric acid was probably not the cause of the disease since hypertension - a much more likely cause of renal disease - also developed in most of these patients. ${ }^{33}$ The Framingham Heart Study reported that uric acid was not a causal risk factor for cardiovascular events because uric acid was not independent of hypertension.

14 However, if uric acid caused hypertension, and hypertension caused kidney disease and heart disease, then uric acid might not be independent of hypertension when evaluated as a risk factor for kidney or heart disease.

\section{HYPERURICEMIC HYPERTENSION}

Recent experimental and clinical evidence supports the possibility that an elevated uric acid level may lead to hypertension (Table 2). Numerous studies have reported that hyperuricemia carries an increased relative risk for hypertension developing within 5 years, independent of other risk factors (Table 3). ${ }^{41-56}$ Studies of uric acid levels and the development of hypertension have generally been consistent, continuous, and of similar magnitude. Hyperuricemia is also common among adults with prehypertension, ${ }^{63}$ especially when microalbuminuria is present. ${ }^{64}$ The observation that hyperuricemia precedes the development of hypertension indicates that it is not simply a result of hypertension per se. Only one study showed that uric acid did not predict the development of hypertension, and it involved subjects in whom hypertension had developed after the age of 60 years. ${ }^{43}$

Hyperuricemia is also more common in primary hypertension than in secondary hypertension, at least in adolescents. ${ }^{11}$ In one study an elevated uric acid level $(>5.5 \mathrm{mg}$ per deciliter [330 $\mu$ mol per liter]) was observed in nearly $90 \%$ of adolescents with essential hypertension, whereas uric acid levels were significantly lower in controls and teens with either white-coat or secondary hypertension. ${ }^{11}$ The observation that uric acid levels were not elevated in secondary hypertension also reduces the likelihood that the hyperuricemia results from hypertension. Interestingly, the relationship of uric acid levels to hypertension in people with established hypertension varies. In some studies hyperuricemia is present in 40 to $60 \%$ of subjects with untreated hypertension, $2,65,66$ whereas other studies reported lower frequencies. ${ }^{2,67}$ Some of the variability might be due to the inclusion of patients with secondary hypertension in various reports. Furthermore, the strength of the relationship between uric acid level and hypertension decreases with increasing patient age and duration of hypertension, ${ }^{68}$ suggesting that uric acid may be most important in younger subjects with early-onset hypertension.

The development of a model of mild hyperuricemia in animals provided the first direct evidence that uric acid elevation may lead to blood-pressure elevation. In this regard, it is worth noting that humans and apes have higher uric acid levels than most other mammals, since they lack the hepatic enzyme uricase, which degrades uric acid to allantoin. To render rats hyperuricemic (which is necessary in order to use them as an animal model), they are treated with a uricase inhibitor. In this model, several weeks after the uric acid level is increased, hypertension develops. In such animals, blood pressure correlated directly with serum levels of uric acid and decreased when uric acid was reduced with either a xanthine oxidase inhibitor or a uricosuric agent. ${ }^{59}$ In this model, the hypertension was shown to be due to uric acid-mediated renal 
vasoconstriction resulting from a reduction in endothelial levels of nitric oxide, with activation of the renin-angiotensin system. ${ }^{69-71}$ Consistent with these observations, elevated uric acid levels in humans also correlate with endothelial dysfunction and increases in plasma renin activity. ${ }^{72-75}$

Over time, microvascular renal disease - with histology that is similar to arteriolosclerosis, the classic lesion of essential hypertension - develops in rats with hyperuricemia. ${ }^{70,76}$ The observation that the microvascular changes still developed, even when blood pressure was controlled by a diuretic, coupled with the demonstration of direct effects of uric acid on endothelial cells and vascular smooth-muscle cells, suggests that uric acid may cause microvascular disease independently of hypertension. 77,78 For example, in experiments with cultured vascular smooth-muscle cells, uric acid induces cellular proliferation, inflammation, oxidative stress, and activation of the local renin-angiotensin system. $59,69,77,79,80$

The development of renal microvascular lesions may provide an additional mechanism by which uric acid can cause hypertension. For example, similar microvascular lesions can be induced in rats with normal serum levels of uric acid through the infusion of angiotensin II or blockage of nitric oxide synthesis. Once these lesions are induced, a salt-sensitive hypertension develops and persists even when infusion of angiotensin II is stopped or the blockade of nitric oxide synthesis is reversed. ${ }^{81,82}$ In another study of rats with hyperuricemia, when the uricase inhibitor was stopped after renal microvascular disease and interstitial inflammation had become pronounced, blood pressure would improve only if the rats remained on a low-salt diet. ${ }^{76}$ Both the experimental and human studies provide a possible explanation for how uric acid might cause hypertension in humans (Fig. 1). Furthermore, the experimental studies provide a rationale as to why uric acid would be linked with newly diagnosed or early-onset hypertension, since subjects with longstanding hypertension might already have renal microvascular disease that could be primarily responsible for their current hypertensive condition.

Preliminary clinical trial data also support a role for uric acid in early-onset primary hypertension. After an open-label pilot study in 5 adolescent patients with hypertension, which indicated that allopurinol lowered blood pressure, ${ }^{79}$ a double-blind, placebo-controlled crossover trial was performed in 30 adolescents with hyperuricemia and hypertension. ${ }^{62}$ In this trial, treatment with allopurinol was associated with a significant reduction in both casual (measured at the physician's office) and ambulatory blood pressure, and the reduction was similar in magnitude to that achieved with most antihypertensive agents $(-6.9 \pm 4.4 \mathrm{~mm} \mathrm{Hg}$ and $-5.1 \pm 2.4 \mathrm{~mm} \mathrm{Hg}$ as compared with $-2.0 \pm 0.4$ and $-2.4 \pm 0.7$ for placebo for casual systolic and diastolic blood pressure, respectively $[\mathrm{P}=0.007$ and $\mathrm{P}=0.03]) .{ }^{62}$ For patients in whom uric acid levels decreased to less than $5 \mathrm{mg}$ per deciliter $(300 \mu \mathrm{mol}$ per liter) during allopurinol therapy, blood pressure became normal in 86\% (19 of 22 patients), as compared with 3\% (1 of 30) during the placebo phase of the study. ${ }^{62}$

There has been a major increase in the prevalence of hypertension worldwide, and there is evidence that uric acid levels are rising as well. ${ }^{18-21}$ Might these two observations be linked? 82 It is widely believed that the increased prevalence of obesity has contributed to the increased prevalence of hypertension. ${ }^{83}$ Over the past 200 years there has been a large increase in fructose intake in the developed world, an increase that correlates temporally with increases in hypertension and obesity. ${ }^{84,85}$ Fructose is unique among sugars in that it rapidly causes depletion of ATP and increases both the generation and the release of uric acid. ${ }^{86}$ Experimental data support a link between fructose intake, hyperuricemia, and increases in blood pressure. For example, the development of hyperuricemia, hypertension, and a metabolic-like syndrome with renal hemodynamic and histologic changes very similar to those observed with hyperuricemia has been reported in rats fed with fructose. Treating these rats with xanthine 
oxidase inhibitors, including allopurinol or febuxostat, lowered uric acid levels and partially prevented these changes. ${ }^{60,87}$ Epidemiologic studies have also linked fructose intake with increased risk of hyperuricemia 88,89 and the metabolic syndrome. ${ }^{90,91}$ Furthermore, although some controversy exists as to whether fructose can induce hypertension in rats, the administration of high-fructose diets to humans can induce many features of the metabolic syndrome, including an acute rise in blood pressure. ${ }^{92,93}$ Thus, one might speculate that fructose-induced hyperuricemia could have a role in the increased prevalence of hypertension worldwide. ${ }^{60,85}$ The ingestion of other foods (such as purine-rich fatty meats) or drinks (such as beer) or exposure to toxins (such as lead, in amounts adequate to cause low-level lead poisoning) that alter uric acid levels may also contribute to elevated uric acid levels and a "hyperuricemic" form of hypertension.

In addition to diet, there is evidence that low birth weight increases the risk of hypertension and obesity later in life. ${ }^{94}$ Among the mechanisms by which low birth weight might lead to an increased risk of hypertension is a congenital reduction in nephron number. ${ }^{95}$ Although there is little direct evidence for this hypothesized mechanism in humans, in one report Keller et al. observed that 10 white subjects with essential hypertension who died in traffic accidents had fewer nephrons than 10 age-matched controls who died similarly. ${ }^{96}$ It is known that mothers who give birth to infants with a low birth weight or infants who are small for gestational age frequently have conditions associated with hyperuricemia, such as preeclampsia, essential hypertension, and obesity. ${ }^{78}$ Uric acid transfers freely from maternal to fetal circulation, and high levels of maternal and fetal uric acid correlate with lower birth weight among infants. ${ }^{8}$, 97 Given the antiangiogenic effects of elevations in uric acid, ${ }^{77}$ it is possible to speculate that such elevations could contribute to low birth weight and reduced nephron number, which might predispose a child to the development of hypertension later in life. ${ }^{78}$

If a child's parent is obese or has hypertension, it is more likely that similar conditions will develop in the child because of genetic or environmental (dietary) traits. In one study, Franco et al. reported that children between 8 and 13 years of age who had been low-birth-weight infants had relatively high uric acid levels and evidence of endothelial dysfunction, though none had hypertension. 98 Another study reported that children whose parents have a history of hypertension have higher uric acid levels, a higher body-mass index (BMI), and higher levels of triglycerides independent of hypertension. ${ }^{99}$ Both lean and obese children of parents with hypertension have been observed to have a low fractional excretion of uric acid and evidence of higher plasma renin activity and increased proximal sodium reabsorption. ${ }^{100}$ We previously reported that adolescents with essential hypertension had relatively high uric acid levels that correlated inversely with their birth weights. ${ }^{11}$

It is also possible that genetic polymorphisms of transporters or enzymes involved in uric acid metabolism affect blood pressure, especially in younger subjects. For example, hypertension has been associated with polymorphisms of xanthine oxidoreductase. ${ }^{101}$ Solute carrier family 2 , member 9 (SLC2A9) is a newly identified fructose and uric acid transporter in which several genetic polymorphisms have been identified that are associated with an increased risk of gout. 102,103 Nevertheless, these polymorphisms were not observed to be associated with hypertension. ${ }^{102}$ This result may indicate that uric acid is not a direct causal risk factor for hypertension, or it might reflect the fact that polymorphisms in SLC2A9 account for only a small fraction of the variance in serum uric acid, meaning that it may be difficult to detect an effect. 102,103

\section{URIC ACID, THE METABOLIC SYNDROME, AND DIABETES}

Increasing evidence suggests that uric acid may play a role in the metabolic syndrome. Historically, the elevated level of uric acid observed in the metabolic syndrome has been 
attributed to hyperinsulinemia, since insulin reduces renal excretion of uric acid. 30 Hyperuricemia, however, often precedes the development of hyperinsulinemia, ${ }^{12,104}$ obesity, 48 and diabetes. $51,57,105$ Hyperuricemia may also be present in the metabolic syndrome in people who are not overweight or obese. In one study only $5.9 \%$ of subjects with a normal BMI and a uric acid level of less than $6.0 \mathrm{mg}$ per deciliter $(360 \mu \mathrm{mol}$ per liter $)$ had the metabolic syndrome; in contrast, $59 \%$ of subjects with a normal BMI and a uric acid level of more than $10 \mathrm{mg}$ per deciliter ( $60 \mu \mathrm{mol}$ per liter) had evidence of the metabolic syndrome. ${ }^{106}$

The strongest evidence of a role for uric acid in the development of the metabolic syndrome has been from studies in animal models showing that decreasing uric acid levels can prevent or reverse features of the metabolic syndrome. $60,87,107$ Two mechanisms have been suggested to explain how hyperuricemia might induce the metabolic syndrome. The first mechanism is related to the fact that glucose uptake in skeletal muscle depends in part on increases in blood flow mediated by the insulin-stimulated release of nitric oxide from endothelial cells. Features of the metabolic syndrome develop in mice lacking endothelial nitric oxide synthase. 108 The observations that hyperuricemia can induce endothelial dysfunction in rats ${ }^{69}$ and that treatment with allopurinol can improve endothelial function in patients with hyperuricemia 74 would support this mechanism. The second mechanism concerns the inflammatory and oxidative changes uric acid induces in adipocytes, ${ }^{109}$ a process that is key in causing the metabolic syndrome in obese mice. ${ }^{110}$ In addition, xanthine oxidoreductase (the enzyme that generates uric acid from xanthine) is expressed in adipocytes and is critical to the process of adipogenesis; indeed, xanthine oxidoreductase knockout mice have only half the adipocyte mass of their control littermates. 111

\section{URIC ACID AND CHRONIC KIDNEY DISEASE}

Both experimental and clinical studies suggest the possibility that an elevated level of uric acid itself can lead to kidney disease without the deposition of uric acid crystals. ${ }^{58,59}$ Experimental studies in rats have shown that raising uric acid levels can cause de novo kidney disease as well as accelerate existing kidney disease. 58,59 The principal lesions from increased uric acid in the rat are glomerulosclerosis, interstitial fibrosis, and arteriolar disease, conditions similar to those observed in "gouty" nephropathy, except for the absence of intrarenal urate crystals. 58,59 The mechanism of injury appears to be related to the development of preglomerular arteriolar disease that impairs the renal autoregulatory response and thereby causes glomerular hypertension. ${ }^{112}$ Similar histologic findings are also present in the hereditary human disease familial juvenile hyperuricemic nephropathy.

More recent epidemiologic studies also suggest that uric acid may have a role in causing renal disease. For example, an elevated uric acid level is an independent predictor of the development of both microalbuminuria ${ }^{64}$ and renal dysfunction in subjects with normal renal function ${ }^{38-}$ 40 and is associated with an impaired glomerular filtration rate in patients with type 1 diabetes who do not have proteinuria. ${ }^{113}$ In contrast, the uric acid level does not predict the renal progression of established chronic kidney disease, ${ }^{114}$ suggesting that in established disease structural (and nonreversible) microvascular and glomerular lesions have already developed and are driving disease progression independently of uric acid levels. 71,76

Recent studies suggest that lowering levels of uric acid may slow progression of renal disease, especially in patients with hyperuricemia. Siu et al. reported that the treatment of asymptomatic hyperuricemia in patients with mild renal disease (chronic kidney disease at stage 3) resulted in delayed disease progression. ${ }^{9}$ Likewise, Kanbay et al. recently reported that treatment of asymptomatic hyperuricemia improved renal function. ${ }^{61}$ Talaat et al. used a different approach in which they withdrew allopurinol from a group of patients with chronic kidney disease who were in stable condition. This withdrawal resulted in worsening of hypertension and 
acceleration of kidney dysfunction in the patients who were not taking angiotensin-convertingenzyme inhibitors. ${ }^{10}$

\section{OTHER CARDIOVASCULAR DISEASES ASSOCIATED WITH HYPERURICEMIA}

Hyperuricemia is strongly associated with peripheral, carotid, and coronary vascular disease,

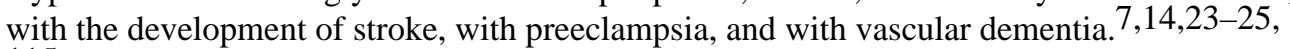
115 The relationship of uric acid with cardiovascular events is particularly strong, especially in patients at high risk for heart disease and in women. ${ }^{116}$ Some of the cardiovascular benefits of losartan reported in the Losartan Intervention for Endpoint Reduction in Hypertension (LIFE) study 117 and for atorvastatin reported in the Greek Atorvastatin and Coronary-HeartDisease Evaluation (GREACE) study ${ }^{118}$ have also been attributed to the ability of these drugs to lower uric acid levels. Whether uric acid has a causal relationship in these conditions remains to be determined.

\section{CAVEATS AND FUTURE DIRECTIONS}

There are several important limitations and caveats related to the recent studies we have cited in considering a causal role for uric acid in cardiovascular disease. First, most of the clinical trials we referenced are small and examined highly defined populations. For example, it is not known whether lowering uric acid levels with allopurinol will be effective in people with more severe or longstanding hypertension as compared with those in the preliminary studies cited. Nor do we know whether the beneficial effect of allopurinol observed in completed and preliminary human studies is due to the reduction of uric acid or to a reduction in xanthine oxidase-associated oxidants. Although the experimental studies suggest that the benefit results from lowering uric acid, $70,77,79,80,119,120$ the improvement of endothelial function observed in patients with hyperuricemia and heart failure or diabetes occurred among patients who received allopurinol but not among those receiving other drugs designed to lower uric acid levels. ${ }^{121,122}$ One possible explanation for this result is that xanthine oxidase inhibitors are more effective than other agents in lowering intracellular levels of uric acid, and consequently had a greater influence on intracellular regulation of endothelial vascular activity. 77 Alternatively, uric acid may be more of a marker, and the benefit of allopurinol may be the result of its ability to block xanthine oxidase-associated oxidants.

We also need a better understanding of the biologic functions of uric acid as they may relate to cardiovascular disease. Although uric acid may have proinflammatory effects on vascular cells and adipocytes, it can also function as an antioxidant. ${ }^{26,123,124}$ It has been suggested that the antioxidant effects of uric acid are protective in several neurologic diseases, including multiple sclerosis and Parkinson's disease. Conversely, uric acid can also function as a prooxidant, either by generating radicals during its degradation or by stimulating NADPH oxidase. 109,125 Uric acid can also stimulate innate immunity through the effects of microcrystalline uric acid on the function of dendritic cells and T cells. ${ }^{126,127}$ Studies by our group and others also suggest a role for T cells in the pathogenesis of salt-sensitive hypertension. 128,129 Thus, it remains possible that uric acid may have a variety of as yet incompletely defined actions in cardiovascular disease.

Right now there are not sufficient data to recommend the treatment of asymptomatic hyperuricemia. Allopurinol is not a benign drug, and may occasionally precipitate a hypersensitivity syndrome that can be fatal. The data reviewed in this article are the basis for a hypothesis that still needs to be tested. 


\section{Acknowledgements}

Supported by grants from the U.S. Public Health Service (HL-68607 and DK-52121, to Dr. Johnson; and DK064587, to Dr. Feig) and from the Korea Science and Engineering Foundation through the government of Korea, Ministry of Education, Science, and Technology (R01-2008-000-10845-0, to Dr. Kang).

\section{References}

1. Davis N. The cardiovascular and renal relations and manifestations of gout. JAMA 1897;29:261-2.

2. Cannon PJ, Stason WB, Demartini FE, Sommers SC, Laragh JH. Hyperuricemia in primary and renal hypertension. N Engl J Med 1966;275:457-64. [PubMed: 5917940]

3. Gertler MM, Garn SM, Levine SA. Serum uric acid in relation to age and physique in health and in coronary heart disease. Ann Intern Med 1951;34:1421-31. [PubMed: 14838504]

4. Ford ES, Li C, Cook S, Choi HK. Serum concentrations of uric acid and the metabolic syndrome among US children and adolescents. Circulation 2007;115:2526-32. [PubMed: 17470699]

5. Tuttle KR, Short RA, Johnson RJ. Sex differences in uric acid and risk factors for coronary artery disease. Am J Cardiol 2001;87:1411-4. [PubMed: 11397367]

6. Lehto S, Niskanen L, Rönnemaa T, Laakso M. Serum uric acid is a strong predictor of stroke in patients with non-insulin-dependent diabetes mellitus. Stroke 1998;29:635-9. [PubMed: 9506605]

7. Schretlen DJ, Inscore AB, Vannorsdall TD, et al. Serum uric acid and brain ischemia in normal elderly adults. Neurology 2007;69:1418-23. [PubMed: 17909154]

8. Roberts JM, Bodnar LM, Lain KY, et al. Uric acid is as important as proteinuria in identifying fetal risk in women with gestational hypertension. Hypertension 2005;46:1263-9. [PubMed: 16246973]

9. Siu YP, Leung KT, Tong MK, Kwan TH. Use of allopurinol in slowing the progression of renal disease through its ability to lower serum uric acid level. Am J Kidney Dis 2006;47:51-9. [PubMed: 16377385]

10. Talaat KM, el-Sheikh AR. The effect of mild hyperuricemia on urinary transforming growth factor beta and the progression of chronic kidney disease. Am J Nephrol 2007;27:435-40. [PubMed: 17622758]

11. Feig DI, Johnson RJ. Hyperuricemia in childhood primary hypertension. Hypertension 2003;42:24752. [PubMed: 12900431]

12. Nakagawa T, Tuttle KR, Short RA, Johnson RJ. Fructose-induced hyperuricemia as a casual mechanism for the epidemic of the metabolic syndrome. Nat Clin Pract Nephrol 2005;1:80-6. [PubMed: 16932373]

13. Niskanen LK, Laaksonen DE, Nyyssönen K, et al. Uric acid level as a risk factor for cardiovascular and all-cause mortality in middle-aged men: a prospective cohort study. Arch Intern Med 2004;164:1546-51. [PubMed: 15277287]

14. Culleton BF, Larson MG, Kannel WB, Levy D. Serum uric acid and risk for cardiovascular disease and death: the Framingham Heart Study. Ann Intern Med 1999;131:7-13. [PubMed: 10391820]

15. Chobanian AV, Bakris GL, Black HR, et al. The Seventh Report of the Joint National Committee on Prevention, Detection, Evaluation, and Treatment of High Blood Pressure: the JNC 7 report. JAMA 2003;289:2560-72. [PubMed: 12748199][Erratum, JAMA 2003;290:197.]

16. Pearson TA, Blair SN, Daniels SR, et al. AHA Guidelines for Primary Prevention of Cardiovascular Disease and Stroke: 2002 Update: Consensus Panel Guide to Comprehensive Risk Reduction for Adult Patients Without Coronary or Other Atherosclerotic Vascular Diseases. Circulation 2002;106:388-91. [PubMed: 12119259]

17. Johnson RJ, Titte S, Cade JR, Rideout BA, Oliver WJ. Uric acid, evolution and primitive cultures. Semin Nephrol 2005;25:3-8. [PubMed: 15660328]

18. Fishberg AM. The interpretation of increased blood uric acid in hypertension. Arch Intern Med 1924;34:503-7.

19. Jacobson BM. The uric acid in the serum of gouty and non-gouty individuals: its determination by Folin's recent method and its signficance in the diagnosis of gout. Ann Intern Med 1938;11:127795.

20. Hall AP, Barry PE, Dawber TR, McNamara PM. Epidemiology of gout and hyperuricemia: a longterm population study. Am J Med 1967;42:27-37. [PubMed: 6016478] 
21. Freedman DS, Williamson DF, Gunter EW, Byers T. Relation of serum uric acid to mortality and ischemic heart disease: the NHANES I Epidemiologic Follow-up Study. Am J Epidemiol 1995;141:637-44. [PubMed: 7702038]

22. Adamopoulos D, Vlassopoulos C, Seitanides B, Contoyiannis P, Vassilopoulos P. The relationship of sex steroids to uric acid levels in plasma and urine. Acta Endocrinol (Copenh) 1977;85:198-208. [PubMed: 577077]

23. Moriarity JT, Folsom AR, Iribarren C, Nieto FJ, Rosamond WD. Serum uric acid and risk of coronary heart disease: Atherosclerosis Risk in Communities (ARIC) Study. Ann Epidemiol 2000;10:136-43. [PubMed: 10813506]

24. Wannamethee SG, Shaper AG, Whin-cup PH. Serum urate and the risk of major coronary heart disease events. Heart 1997;78:147-53. [PubMed: 9326988]

25. Wheeler JG, Juzwishin KD, Eiriksdottir G, Gudnason V, Danesh J. Serum uric acid and coronary heart disease in 9,458 incident cases and 155,084 controls: prospective study and meta-analysis. PLoS Med 2005;2(3):e76. [PubMed: 15783260]

26. Ames BN, Cathcart R, Schwiers E, Hochstein P. Uric acid provides an anti-oxidant defense in humans against oxidant- and radical-caused aging and cancer: a hypothesis. Proc Natl Acad Sci U S A 1981;78:6858-62. [PubMed: 6947260]

27. Nieto FJ, Iribarren C, Gross MD, Comstock GW, Cutler RG. Uric acid and serum antioxidant capacity: a reaction to atherosclerosis? Atherosclerosis 2000;148:131-9. [PubMed: 10580179]

28. Cappuccio FP, Strazzullo P, Farinaro E, Trevisan M. Uric acid metabolism and tubular sodium handling: results from a population-based study. JAMA 1993;270:354-9. [PubMed: 8315780]

29. Messerli FH, Frohlich ED, Dreslinski GR, Suarez DH, Aristimuno GG. Serum uric acid in essential hypertension: an indicator of renal vascular involvement. Ann Intern Med 1980;93:817-21. [PubMed: 7447188]

30. Quiñones Galvan A, Natali A, Baldi S, et al. Effect of insulin on uric acid excretion in humans. Am J Physiol 1995;268:E1-E5. [PubMed: 7840165]

31. Coombs FS, Pecora LJ, Thorogood E, Consolazio WV, Talbott JH. Renal function in patients with gout. J Clin Invest 1940;19:525-35. [PubMed: 16694770]

32. Talbott JH, Terplan KL. The kidney in gout. Medicine (Baltimore) 1960;39:405-67. [PubMed: 13775026]

33. Yü TF, Berger L, Dorph DJ, Smith H. Renal function in gout. V. Factors influencing the renal hemodynamics. Am J Med 1979;67:766-71. [PubMed: 507087]

34. Yü TF, Berger L. Impaired renal function gout: its association with hypertensive vascular disease and intrinsic renal disease. Am J Med 1982;72:95-100. [PubMed: 7058827]

35. Fang J, Alderman MH. Serum uric acid and cardiovascular mortality: the NHANES I epidemiologic follow-up study, 1971-1992. JAMA 2000;283:2404-10. [PubMed: 10815083]

36. Alderman MH, Cohen H, Madhavan S, Kivlighn S. Serum uric acid and cardiovascular events in successfully treated hypertensive patients. Hypertension 1999;34:144-50. [PubMed: 10406838]

37. Niskanen L, Laaksonen DE, Lindström J, et al. Serum uric acid as a harbinger of metabolic outcome in subjects with impaired glucose tolerance: the Finnish Diabetes Prevention Study. Diabetes Care 2006;29:709-11. [PubMed: 16505534]

38. Iseki K, Ikemiya Y, Inoue T, Iseki C, Kinjo K, Takishita S. Significance of hyperuricemia as a risk factor for developing ESRD in a screened cohort. Am J Kidney Dis 2004;44:642-50. [PubMed: 15384015]

39. Iseki K, Oshiro S, Tozawa M, Iseki C, Ikemiya Y, Takishita S. Significance of hyperuricemia on the early detection of renal failure in a cohort of screened subjects. Hypertens Res 2001;24:691-7. [PubMed: 11768729]

40. Tomita M, Mizuno S, Yamanaka H, et al. Does hyperuricemia affect mortality? A prospective cohort study of Japanese male workers. J Epidemiol 2000;10:403-9. [PubMed: 11210110]

41. Alper AB Jr, Chen W, Yau L, Srinivasan SR, Berenson GS, Hamm LL. Childhood uric acid predicts adult blood pressure: the Bogalusa Heart Study. Hypertension 2005;45:34-8. [PubMed: 15569853]

42. Dyer AR, Liu K, Walsh M, Kiefe C, Jacobs DR Jr, Bild DE. Ten-year incidence of elevated blood pressure and its predictors: the CARDIA study. J Hum Hypertens 1999;13:13-21. [PubMed: 9928747] 
43. Forman JP, Choi H, Curhan GC. Plasma uric acid level and risk for incident hypertension among men. J Am Soc Nephrol 2007;18:287-92. [PubMed: 17167112]

44. Hunt SC, Stephenson SH, Hopkins PN, Williams RR. Predictors of an increased risk of future hypertension in Utah: a screening analysis. Hypertension 1991;17:969-76. [PubMed: 2045178]

45. Imazu M, Yamamoto H, Toyofuku M, et al. Hyperinsulinemia for the development of hypertension: data from the Hawaii-Los Angeles-Hiroshima Study. Hypertens Res 2001;24:531-6. [PubMed: 11675947]

46. Jossa F, Farinaro E, Panico S, et al. Serum uric acid and hypertension: the Olivetti Heart Study. J Hum Hypertens 1994;8:677-81. [PubMed: 7807497]

47. Krishnan E, Kwoh CK, Schumacher HR, Kuller L. Hyperuricemia and incidence of hypertension among men without metabolic syndrome. Hypertension 2007;49:298-303. [PubMed: 17190877]

48. Masuo K, Kawaguchi H, Mikami H, Ogihara T, Tuck ML. Serum uric acid and plasma norepinephrine concentrations predict subsequent weight gain and blood pressure elevation. Hypertension 2003;42:474-80. [PubMed: 12953019]

49. Mellen PB, Bleyer AJ, Erlinger TP, et al. Serum uric acid predicts incident hypertension in a biethnic cohort: the Atherosclerosis Risk in Communities study. Hypertension 2006;48:1037-42. [PubMed: 17060502]

50. Nagahama K, Inoue T, Iseki K, et al. Hyperuricemia as a predictor of hypertension in a screened cohort in Okinawa, Japan. Hypertens Res 2004;27:835-41. [PubMed: 15824465]

51. Nakanishi N, Okamoto M, Yoshida H, Matsuo Y, Suzuki K, Tatara K. Serum uric acid and risk for development of hypertension and impaired fasting glucose or Type II diabetes in Japanese male office workers. Eur J Epidemiol 2003;18:523-30. [PubMed: 12908717]

52. Perlstein TS, Gumieniak O, Williams GH, et al. Uric acid and the development of hypertension: the Normative Aging Study. Hypertension 2006;48:1031-6. [PubMed: 17060508]

53. Selby JV, Friedman GD, Quesenberry CP Jr. Precursors of essential hypertension: pulmonary function, heart rate, uric acid, serum cholesterol, and other serum chemistries. Am J Epidemiol 1990;131:1017-27. [PubMed: 2343854][Erratum, Am J Epidemiol 1990;132:589.]

54. Shankar A, Klein R, Klein BE, Nieto FJ. The association between serum uric acid level and longterm incidence of hypertension: population-based cohort study. J Hum Hypertens 2006;20:937-45. [PubMed: 17024135]

55. Sundström J, Sullivan L, D’Agostino RB, Levy D, Kannel WB, Vasan RS. Relations of serum uric acid to longitudinal blood pressure tracking and hypertension incidence. Hypertension 2005;45:2833. [PubMed: 15569852]

56. Taniguchi Y, Hayashi T, Tsumura K, Endo G, Fujii S, Okada K. Serum uric acid and the risk for hypertension and Type 2 diabetes in Japanese men: the Osaka Health Survey. J Hypertens 2001;19:1209-15. [PubMed: 11446710]

57. Dehghan A, van Hoek M, Sijbrands EJ, Hofman A, Witteman JC. High serum uric acid as a novel risk factor for type 2 diabetes. Diabetes Care 2008;31:361-2. [PubMed: 17977935]

58. Kang DH, Nakagawa T, Feng L, et al. A role for uric acid in the progression of renal disease. J Am Soc Nephrol 2002;13:2888-97. [PubMed: 12444207]

59. Mazzali M, Hughes J, Kim YG, et al. Elevated uric acid increases blood pressure in the rat by a novel crystal-independent mechanism. Hypertension 2001;38:1101-6. [PubMed: 11711505]

60. Nakagawa T, Hu H, Zharikov S, et al. A causal role for uric acid in fructose-induced metabolic syndrome. Am J Physiol Renal Physiol 2006;290:F625-F631. [PubMed: 16234313]

61. Kanbay M, Ozkara A, Selcoki Y, et al. Effect of treatment of hyperuricemia with allopurinol on blood pressure, creatinine clearence, and proteinuria in patients with normal renal functions. Int Urol Nephrol 2007;39:1227-33. [PubMed: 17701281]

62. Feig DI, Soletsky B, Johnson RJ. Effect of allopurinol on the blood pressure of adolescents with newly diagnosed essential hypertension. JAMA 2008;300:924-32. [PubMed: 18728266]

63. Syamala S, Li J, Shankar A. Association between serum uric acid and prehypertension among US adults. J Hypertens 2007;25:1583-9. [PubMed: 17620953]

64. Lee JE, Kim YG, Choi YH, Huh W, Kim DJ, Oh HY. Serum uric acid is associated with microalbuminuria in prehypertension. Hypertension 2006;47:962-7. [PubMed: 16520402] 
65. Bulpitt CJ. Serum uric acid in hypertensive patients. Br Heart J 1975;37:1210-5. [PubMed: 1225335]

66. Kinsey D, Walther R, Sise HS, White-law G, Smithwick R. Incidence of hyperuricemia in 400 hypertensive patients. Circulation 1961;24:972-3.

67. Cuspidi C, Valerio C, Sala C, et al. Lack of association between serum uric acid and organ damage in a never-treated essential hypertensive population at low prevalence of hyperuricemia. Am J Hypertens 2007;20:678-85. [PubMed: 17531928]

68. Brand FN, McGee DL, Kannel WB, Stokes J III, Castelli WP. Hyperuricemia as a risk factor of coronary heart disease: the Framingham Study. Am J Epidemiol 1985;121:11-8. [PubMed: 3964986]

69. Khosla UM, Zharikov S, Finch JL, et al. Hyperuricemia induces endothelial dysfunction. Kidney Int 2005;67:1739-42. [PubMed: 15840020]

70. Mazzali M, Kanellis J, Han L, et al. Hyperuricemia induces a primary renal arteriolopathy in rats by a blood pressure-independent mechanism. Am J Physiol Renal Physiol 2002;282:F991-F997. [PubMed: 11997315]

71. Sánchez-Lozada LG, Tapia E, López-Molina R, et al. Effects of acute and chronic L-arginine treatment in experimental hyperuricemia. Am J Physiol Renal Physiol 2007;292:F1238-F1244. [PubMed: 17190912]

72. Doehner W, Schoene N, Rauchhaus M, et al. Effects of xanthine oxidase inhibition with allopurinol on endothelial function and peripheral blood flow in hyperuricemic patients with chronic heart failure: results from 2 placebo-controlled studies. Circulation 2002;105:2619-24. [PubMed: 12045167]

73. Farquharson CA, Butler R, Hill A, Belch JJ, Struthers AD. Allopurinol improves endothelial dysfunction in chronic heart failure. Circulation 2002;106:221-6. [PubMed: 12105162]

74. Mercuro G, Vitale C, Cerquetani E, et al. Effect of hyperuricemia upon endothelial function in patients at increased cardiovascular risk. Am J Cardiol 2004;94:932-5. [PubMed: 15464681]

75. Saito I, Saruta T, Kondo K, et al. Serum uric acid and the renin-angiotensin system in hypertension. J Am Geriatr Soc 1978;26:241-7. [PubMed: 659766]

76. Watanabe S, Kang DH, Feng L, et al. Uric acid, hominoid evolution, and the pathogenesis of saltsensitivity. Hypertension 2002;40:355-60. [PubMed: 12215479]

77. Kang DH, Park SK, Lee IK, Johnson RJ. Uric acid-induced C-reactive protein expression: implication on cell proliferation and nitric oxide production of human vascular cells. J Am Soc Nephrol 2005;16:3553-62. [PubMed: 16251237]

78. Feig DI, Nakagawa T, Karumanchi SA, et al. Uric acid, nephron number, and the pathogenesis of essential hypertension. Kidney Int 2004;66:281-7. [PubMed: 15200435]

79. Rao GN, Corson MA, Berk BC. Uric acid stimulates vascular smooth muscle cell proliferation by increasing platelet-derived growth factor A-chain expression. J Biol Chem 1991;266:8604-8. [PubMed: 2022672]

80. Corry DB, Eslami P, Yamamoto K, Nyby MD, Makino H, Tuck ML. Uric acid stimulates vascular smooth muscle cell proliferation and oxidative stress via the vascular renin-angiotensin system. $\mathrm{J}$ Hypertens 2008;26:269-75. [PubMed: 18192841]

81. Franco M, Tapia E, Santamaria J, et al. Renal cortical vasoconstriction contributes to development of salt-sensitive hypertension after angiotensin II exposure. J Am Soc Nephrol 2001;12:2263-71. [PubMed: 11675402]

82. Quiroz Y, Pons H, Gordon KL, et al. Mycophenolate mofetil prevents salt-sensitive hypertension resulting from nitric oxide synthesis inhibition. Am J Physiol Renal Physiol 2001;281:F38-F47. [PubMed: 11399644]

83. Davy KP, Hall JE. Obesity and hypertension: two epidemics or one? Am J Physiol Regul Integr Comp Physiol 2004;286:R803-R813. [PubMed: 15068965]

84. Havel PJ. Dietary fructose: implications for dysregulation of energy homeostasis and lipid/ carbohydrate metabolism. Nutr Rev 2005;63:133-57. [PubMed: 15971409]

85. Johnson RJ, Segal MS, Sautin Y, et al. Potential role of sugar (fructose) in the epidemic of hypertension, obesity and the metabolic syndrome, diabetes, kidney disease, and cardiovascular disease. Am J Clin Nutr 2007;86:899-906. [PubMed: 17921363]

86. Hallfrisch J. Metabolic effects of dietary fructose. FASEB J 1990;4:2652-60. [PubMed: 2189777] 
87. Sánchez-Lozada LG, Tapia E, Bautista-García P, et al. Effects of febuxostat on metabolic and renal alterations in rats with fructose-induced metabolic syndrome. Am J Physiol Renal Physiol 2008;294:F710-F718. [PubMed: 18216151]

88. Choi JW, Ford ES, Gao X, Choi HK. Sugar-sweetened soft drinks, diet soft drinks, and serum uric acid level: the Third National Health and Nutrition Examination Survey. Arthritis Rheum 2008;59:109-16. [PubMed: 18163396]

89. Gao X, Qi L, Qiao N, et al. Intake of added sugar and sugar-sweetened drink and serum uric acid concentration in US men and women. Hypertension 2007;50:306-12. [PubMed: 17592072]

90. Ludwig DS, Peterson KE, Gortmaker SL. Relation between consumption of sugar-sweetened drinks and childhood obesity: a prospective, observational analysis. Lancet 2001;357:505-8. [PubMed: 11229668]

91. Schulze MB, Manson JE, Ludwig DS, et al. Sugar-sweetened beverages, weight gain, and incidence of type 2 diabetes in young and middle-aged women. JAMA 2004;292:927-34. [PubMed: 15328324]

92. Segal MS, Gollub E, Johnson RJ. Is the fructose index more relevant with regards to cardiovascular disease than the glycemic index? Eur J Nutr 2007;46:406-17. [PubMed: 17763967]

93. Brown CM, Dulloo AG, Yepuri G, Montani JP. Fructose ingestion acutely elevates blood pressure in healthy young humans. Am J Physiol Regul Integr Comp Physiol 2008;294:R730-R737. [PubMed: 18199590]

94. Barker DJ, Osmond C, Golding J, Kuh D, Wadsworth ME. Growth in utero, blood pressure in childhood and adult life, and mortality from cardiovascular disease. BMJ 1989;298:564-7. [PubMed: 2495113]

95. Brenner BM, Garcia DL, Anderson S. Glomeruli and blood pressure: less of one, more the other? Am J Hypertens 1988;1:335-47. [PubMed: 3063284]

96. Keller G, Zimmer G, Mall G, Ritz E, Amann K. Nephron number in patients with primary hypertension. N Engl J Med 2003;348:101-8. [PubMed: 12519920]

97. Chang FM, Chow SN, Huang HC, et al. The placental transfer and concentration difference in maternal and neonatal serum uric acid at parturition: comparison of normal pregnancies and gestosis. Biol Res Pregnancy Perinatol 1987;8:35-9. [PubMed: 3580446]

98. Franco MC, Christofalo DM, Sawaya AL, Ajzen SA, Sesso R. Effects of low birth weight in 8- to 13-year-old children: implications in endothelial function and uric acid levels. Hypertension 2006;48:45-50. [PubMed: 16682609]

99. Ueno M, Tomita Y, Tsuchihashi T, Takishita S, Fujishima M. Clinical alterations in normotensive offspring with parental hypertension. J Hypertens Suppl 1988;6:S50-S51. [PubMed: 3241242]

100. Simsolo RB, Romo MM, Rabinovich L, Bonanno M, Grunfeld B. Family history of essential hypertension versus obesity as risk factors for hypertension in adolescents. Am J Hypertens 1999;12:260-3. [PubMed: 10192227]

101. Chaves FJ, Corella D, Blesa S, et al. Xanthine oxidoreductase polymorphisms: influence in blood pressure and oxidative stress levels. Pharmacogenet Genomics 2007;17:589-96. [PubMed: 17622935]

102. Vitart V, Rudan I, Hayward C, et al. SLC2A9 is a newly identified urate transporter influencing serum urate concentration, urate excretion and gout. Nat Genet 2008;40:437-42. [PubMed: 18327257]

103. Döring A, Gieger C, Mehta D, et al. SLC2A9 influences uric acid concentrations with pronounced sex-specific effects. Nat Genet 2008;40:430-6. [PubMed: 18327256]

104. Carnethon MR, Fortmann SP, Palaniappan L, Duncan BB, Schmidt MI, Chambless LE. Risk factors for progression to incident hyperinsulinemia: the Atherosclerosis Risk in Communities Study, 1987-1998. Am J Epidemiol 2003;158:1058-67. [PubMed: 14630601]

105. Chien KL, Chen MF, Hsu HC, et al. Plasma uric acid and the risk of type 2 diabetes in a Chinese community. Clin Chem 2008;54:310-6. [PubMed: 18089655]

106. Choi HK, Ford ES. Prevalence of the metabolic syndrome in individuals with hyperuricemia. Am J Med 2007;120:442-7. [PubMed: 17466656]

107. Reungjui S, Roncal CA, Mu W, et al. Thiazide diuretics exacerbate fructose-induced metabolic syndrome. J Am Soc Nephrol 2007;18:2724-31. [PubMed: 17855639] 
108. Cook S, Hugli O, Egli M, et al. Clustering of cardiovascular risk factors mimicking the human metabolic syndrome X in eNOS null mice. Swiss Med Wkly 2003;133:360-3. [PubMed: 12947532]

109. Sautin YY, Nakagawa T, Zharikov S, Johnson RJ. Adverse effects of the classical antioxidant uric acid in adipocytes: NADPH oxidase-mediated oxidative/nitrosative stress. Am J Physiol Cell Physiol 2007;293:C584-C596. [PubMed: 17428837]

110. Furukawa S, Fujita T, Shimabukuro M, et al. Increased oxidative stress in obesity and its impact on metabolic syndrome. J Clin Invest 2004;114:1752-61. [PubMed: 15599400]

111. Cheung KJ, Tzameli I, Pissios P, et al. Xanthine oxidoreductase is a regulator of adipogenesis and PPARgamma activity. Cell Metab 2007;5:115-28. [PubMed: 17276354]

112. Sánchez-Lozada LG, Tapia E, Santamaría J, et al. Mild hyperuricemia induces vasoconstriction and maintains glomerular hypertension in normal and remnant kidney rats. Kidney Int 2005;67:23747. [PubMed: 15610247]

113. Rosolowsky ET, Ficociello LH, Maselli NJ, et al. High-normal serum uric acid is associated with impaired glomerular filtration rate in nonproteinuric patients with type 1 diabetes. Clin J Am Soc Nephrol 2008;3:706-13. [PubMed: 18272826]

114. Hunsicker LG, Adler S, Caggiula A, et al. Predictors of the progression of renal disease in the Modification of Diet in Renal Disease Study. Kidney Int 1997;51:1908-19. [PubMed: 9186882]

115. Bos MJ, Koudstaal PJ, Hofman A, Witteman JC, Breteler MM. Uric acid is a risk factor for myocardial infarction and stroke: the Rotterdam Study. Stroke 2006;37:1503-7. [PubMed: 16675740]

116. Baker JF, Krishnan E, Chen L, Schumacher HR. Serum uric acid and cardiovascular disease: recent developments, and where do they leave us? Am J Med 2005;118:816-26. [PubMed: 16084170]

117. Høieggen A, Alderman MH, Kjeldsen SE, et al. The impact of serum uric acid on cardiovascular outcomes in the LIFE study. Kidney Int 2004;65:1041-9. [PubMed: 14871425]

118. Athyros VG, Elisaf M, Papageorgiou AA, et al. Effect of statins versus untreated dyslipidemia on serum uric acid levels in patients with coronary heart disease: a subgroup analysis of the GREek Atorvastatin and Coronary-heart-disease Evaluation (GREACE) study. Am J Kidney Dis 2004;43:589-99. [PubMed: 15042535]

119. Kanellis J, Watanabe S, Li JH, et al. Uric acid stimulates monocyte chemoattractant protein-1 production in vascular smooth muscle cells via mitogen-activated protein kinase and cyclooxygenase-2. Hypertension 2003;41:1287-93. [PubMed: 12743010]

120. Kang DH, Han L, Ouyang X, et al. Uric acid causes vascular smooth muscle cell proliferation by entering cells via a functional urate transporter. Am J Nephrol 2005;25:425-33. [PubMed: 16113518]

121. George J, Carr E, Davies J, Belch JJ, Struthers A. High-dose allopurinol improves endothelial function by profoundly reducing vascular oxidative stress and not by lowering uric acid. Circulation 2006;114:2508-16. [PubMed: 17130343]

122. Waring WS, McKnight JA, Webb DJ, Maxwell SR. Lowering serum urate does not improve endothelial function in patients with type 2 diabetes. Diabetologia 2007;50:2572-9. [PubMed: 17928991]

123. Waring WS, Convery A, Mishra V, Shenkin A, Webb DJ, Maxwell SR. Uric acid reduces exerciseinduced oxidative stress in healthy adults. Clin Sci (Lond) 2003;105:425-30. [PubMed: 12801243]

124. Waring WS, McKnight JA, Webb DJ, Maxwell SR. Uric acid restores endothelial function in patients with type 1 diabetes and regular smokers. Diabetes 2006;55:3127-32. [PubMed: 17065352]

125. Santos CX, Anjos EI, Augusto O. Uric acid oxidation by peroxynitrite: multiple reactions, free radical formation, and amplification of lipid oxidation. Arch Biochem Biophys 1999;372:285-94. [PubMed: 10600166]

126. Shi Y, Evans JE, Rock KL. Molecular identification of a danger signal that alerts the immune system to dying cells. Nature 2003;425:516-21. [PubMed: 14520412]

127. Shi Y, Galusha SA, Rock KL. Cutting edge: elimination of an endogenous adjuvant reduces the activation of CD8 T lymphocytes to transplanted cells and in an autoimmune diabetes model. J Immunol 2006;176:3905-8. [PubMed: 16547223]

128. Guzik TJ, Hoch NE, Brown KA, et al. Role of the T cell in the genesis of angiotensin II induced hypertension and vascular dysfunction. J Exp Med 2007;204:2449-60. [PubMed: 17875676] 
129. Johnson RJ, Herrera-Acosta J, Schreiner GF, Rodriguez-Iturbe B. Subtle acquired renal injury as a mechanism of salt-sensitive hypertension. N Engl J Med 2002;346:913-23. [PubMed: 11907292] 


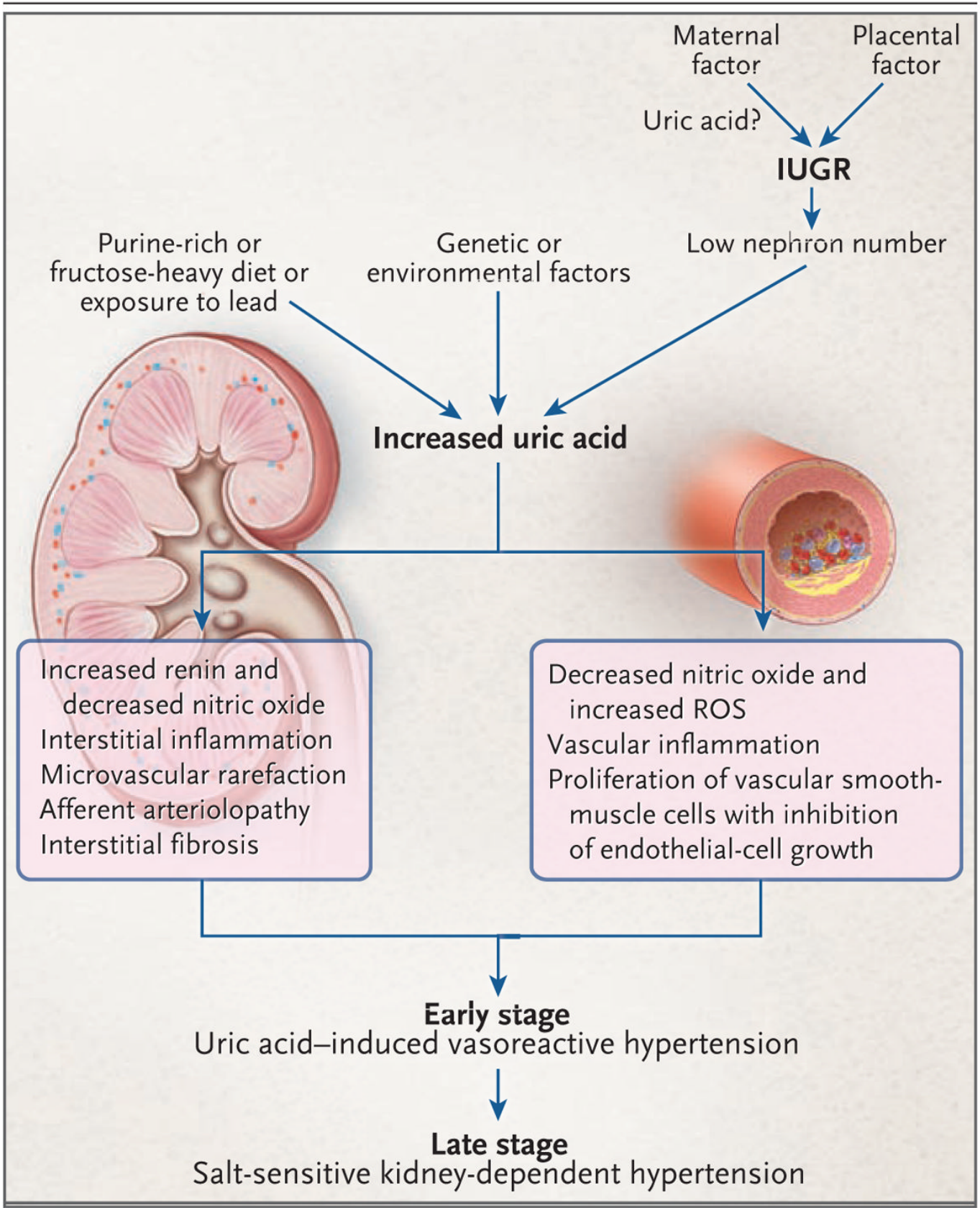

Figure 1. Proposed Mechanism for Uric Acid-Mediated Hypertension

Excessive intake of fructose or purine-rich meats or exposure to low doses of lead may result in chronic hyperuricemia. Mothers with high uric acid levels that are the result of diet or conditions such as preexisting hypertension, obesity, or preeclampsia may transfer uric acid into the fetal circulation through the placenta, which may ultimately contribute to intrauterine growth retardation (IUGR) and a reduction in nephron number. Among babies born with a low nephron number, hyperuricemia may develop in childhood because of genetic or environmental factors. Chronic hyperuricemia would stimulate the renin-angiotensin system and inhibit release of endothelial nitric oxide, contributing to renal vasoconstriction and possibly increasing blood pressure. Persistent renal vasoconstriction may contribute to arteriolosclerosis 
and the development of salt-sensitive hypertension, even if the hyperuricemia is corrected. ROS denotes reactive oxygen species. 
Table 1

Cardiovascular Conditions and Risk Factors Associated with Elevated Uric Acid.

Hypertension and prehypertension

Renal disease (including reduced glomerular filtration rate and microalbuminuria)

Metabolic syndrome (including abdominal obesity, hypertriglyceridemia, low level of high-density lipoprotein cholesterol, insulin resistance, impaired glucose tolerance, elevated leptin level)

Obstructive sleep apnea

Vascular disease (carotid, peripheral, coronary artery)

Stroke and vascular dementia

Preeclampsia

Inflammation markers (C-reactive protein, plasminogen activator inhibitor type 1, soluble intercellular adhesion molecule type 1)

Endothelial dysfunction

Oxidative stress

Sex and race (postmenopausal women, blacks)

Demographic (movement from rural to urban communities, Westernization, immigration to Western cultures) 
Table 2

Evidence Linking Uric Acid and Hypertension.

An elevated uric acid level consistently predicts the development of hypertension.

An elevated uric acid level is observed in $25-60 \%$ of patients with untreated essential hypertension and in nearly $90 \%$ of adolescents with essential hypertension of recent onset.

Raising the uric acid level in rodents results in hypertension with the clinical, hemodynamic, and histologic characteristics of hypertension.

Reducing the uric acid level with xanthine oxidase inhibitors lowers blood pressure in adolescents with hypertension of recent onset. 


\section{Table 3}

Hyperuricemia and the Development of Hypertension.*

\begin{tabular}{|c|c|c|c|}
\hline Study & No. of Patients & Relative Risk of Hypertension & $95 \% \mathrm{CI}$ \\
\hline Kaiser Permanente, $1990^{53}$ & 2062 adults & 2.1 times greater at $6 \mathrm{yr}$ (high vs. low quintile) & $1.20-3.98$ \\
\hline University of Utah, $1991^{44}$ & 1482 adults & 1.44 times greater per $\mathrm{SD}$ increment at $7 \mathrm{yr}$ & $1.03-2.01$ \\
\hline Olivetti Heart, $1994^{46}$ & 619 men & 1.23 times greater per $1 \mathrm{mg} / \mathrm{dl}$ increase at $12 \mathrm{yr}$ & $1.07-1.39$ \\
\hline CARDIA, $1999^{42}$ & 5115 men & 1.21 times greater per $\mathrm{SD}$ increment at $10 \mathrm{yr}$ & $1.03-1.41$ \\
\hline Osaka Health Survey, $2001^{56}$ & 6356 men & 2 times greater at $10 \mathrm{yr}$ (high vs. low quintile) & $1.56-2.60$ \\
\hline Hawaii-Los Angeles-Hiroshima, $2001^{45}$ & 140 men & 2.0 times greater at $15 \mathrm{yr}$ (high vs. low quartile) & $1.02-3.9$ \\
\hline Osaka Factory, $2003^{48}$ & 433 men & $1.0 \mathrm{mg} / \mathrm{dl}$, increased $27 \mathrm{~mm} \mathrm{Hg} \mathrm{SBP}$ at $5 \mathrm{yr}$ & Not calculated \\
\hline Osaka Health Survey, $2003^{51}$ & 2310 men & 1.13 times greater per SD increment at $6 \mathrm{yr}$ & $1.06-1.21$ \\
\hline Okinawa, $2004^{50}$ & 4489 adults & $\begin{array}{l}1.46 \text { times greater for men (uric acid } \geq 7 \mathrm{mg} / \mathrm{dl} \text { ) and } 1.94 \text { for women (uric acid } \geq 6 \\
\mathrm{mg} / \mathrm{dl} \text { ) at } 13 \mathrm{yr}\end{array}$ & $\begin{array}{l}1.09-2.03 \\
1.05-3.57\end{array}$ \\
\hline Bogalusa Heart, $2005^{41}$ & 679 children & Increased risk for diastolic hypertension at $11 \mathrm{yr}$ & Not calculated \\
\hline Framingham Heart, $2005^{55}$ & 3329 adults & 1.17 times greater per $\mathrm{SD}$ increment at $4 \mathrm{yr}$ & $1.02-1.33$ \\
\hline Normative Aging, $2006^{52}$ & 2062 men & 125 times greater at $21 \mathrm{yr}$ (uric acid $>6.5 \mathrm{mg} / \mathrm{dl}$ ) & $1.08-1.34$ \\
\hline ARIC, $2006^{49}$ & 9104 adults & 1.1 times greater per SD increment at $9 \mathrm{yr}$ & $1.02-1.14$ \\
\hline Beaver Dam Health Survey, $2006^{54}$ & 2520 adults & 1.65 times greater at $10 \mathrm{yr}$ (high vs. low quintile) & $1.41-1.93$ \\
\hline Health Professionals' Follow-up, $2006{ }^{43}$ & 750 men & 1.02 times greater per $\mathrm{SD}$ increment at $8 \mathrm{yr}$ & $0.92-1.13$ \\
\hline MRFIT, $2007^{47}$ & 3073 men & 1.1 times greater per $\mathrm{SD}$ increment at $6 \mathrm{yr}$ & $1.02-1.19$ \\
\hline
\end{tabular}

* To convert the values for uric acid to micromoles per liter, multiply by 59.48. ARIC denotes Atherosclerosis Risk in Communities, CARDIA Coronary Artery Risk Development in (Young) Adults, MRFIT Multiple Risk Factors Intervention Trial, and SBP systolic blood pressure. 